\title{
Effect of ginger to overcome nausea and vomiting in pregnant women: a narrative review
}

\author{
Ferilia Adiesti ${ }^{\mathrm{a}, 1^{*}}$, Sulasmi ${ }^{\mathrm{b}, 2}$, Shelly Rodliah Rosyad ${ }^{\mathrm{c}, 3}$, Novia Dwi Jayanti ${ }^{\mathrm{d}, 4}$, Melia Dwi Yitna ${ }^{\mathrm{e}, 5}$ \\ a Sekolah Tinggi Ilmu Kesehatan Majapahit Mojokerto, Indonesia \\ b,c,d,e University 'Aisyiyah Yogyakarta, Indonesia \\ ${ }^{1}$ f.adiesti_april86@yahoo.co.id*; ${ }^{2}$ sulasmi.ami02@gmail.com; ${ }^{3}$ rosyad_shelly@yahoo.com; \\ ${ }^{4}$ nopi833@gmail.com, ${ }^{5}$ Meliadwiyp22@gmail.com \\ $*$ corresponding author
}

ARTICLE INFO

Article history

Received, 29-th June 2021

Revised, $17^{\text {th }}$ August 2021

Accepted, 3-th November 2021

\section{Keywords}

Ginger

Nausea

Vomit

Pregnancy

\section{ABSTRACT}

Background: Nausea, and vomiting (emesis gravidarum) are symptoms that often occur in $60-80 \%$ primigravida and $40-60 \%$ multigravida. Nausea and vomiting are symptoms experienced by women during early pregnancy, where this condition usually begins 4-8 weeks of pregnancy and can be more severe by the $9^{\text {th }}$ week. The condition of nausea and vomiting will improve at 14 weeks of gestation and above. The discovery of the effectiveness of ginger in reducing nausea and vomiting in pregnancy is a potential health technology assessment that can be recommended in midwifery practice. However, a comprehensive analysis is needed regarding the use of ginger in reducing complaints of nausea and vomiting in pregnancy. Therefore, this analysis was conducted to determine how the effect and safetyness of ginger in reducing nausea and vomiting in pregnancy.

Method: The method used was a narrative review method. The articles were searched using 3 databases (PubMed, siencedirect, and Wiley online library). The inclusion criteria of the article were articles published in 2011-2021, in English and discussing the effect of ginger to reduce nausea and vomiting in pregnant women. The article search flow was described using PRISMA Flowchart. Meanwhile, article quality assessment was carried out using MMAT and CASP. Furthermore, data preparation and reporting of results were carried out.

Result: Out of the 10 articles that had been extracted, 9 article involved pregnant women as participants. while 1 article only discusses the effectiveness of ginger in reducing nausea vomiting, 6 articles had been used using randomized controlled trials and 4 articles were systematic reviews. Based on the quality of the articles, 9 articles obtained grade A and 1 article obtained grade B. furthermore, three themes were obtained, namely effectiveness, safety, other therapies, and 5 related sub-themes of effective, ineffective, safety, pharmacological therapy, and nonpharmacological therapy.

Conclusion: The findings of this narrative review found that ginger is effective and safe in reducing nausea and vomiting in pregnancy.

This is an open access article under the CC-BY-SA license.

\section{Introduction}

Nausea and vomiting (emesis gravidarum) are symptoms that often occur in $60-80 \%$ primigravida and 40-60\% multigravida (Mardiyanti \& Zuwariyah, 2019). According to the Ministry of Health of the Republic of Indonesia in 2017 in Wulandari et.al (2019), complaints of nausea and vomiting that 
occur in pregnant women are physiological adaptations. However, this needs to be overcome to reduce discomfort during pregnancy and avoid other complications that may occur, in which body fluids will decrease due to the amount of fluid that comes out of the vomit and it can cause hemoconcentration which can inhibit blood circulation. The effects of these complaints of nausea and vomiting are not only threatening the lives of pregnant women, but also the condition of the babies they are carrying. The consequences can be abortion, premature babies, low birth weight (LBW), and congenital malformations (Afriyanti, 2017).

Nausea and vomiting are common complaints experienced by women during early pregnancy (Javadi et al., 2015). Nausea and vomiting are symptoms experienced by women during early pregnancy, where this condition usually begins 4-8 weeks of pregnancy and can be more severe by the $9^{\text {th }}$ week. The condition of nausea and vomiting will improve at 14 weeks of gestation and above. This nausea and vomiting can continue throughout pregnancy (Omidvar et al., 2014).

Nausea and vomiting are caused by increased levels of estrogen that occur in the first trimester. Changes in the hormone estrogen in pregnancy result in excessive gastric acid secretion, causing nausea and vomiting (Murdiana, 2019). Ginger is efficacious as an anti-vomiting and can be used by pregnant women to reduce morning sickness. Research shows that ginger is very effective in reducing the compound metoclopramide that induces nausea and vomiting. Small white ginger has a higher volatile oil content than elephant ginger. Therefore, it tastes spicier, in addition to high fiber, and is often found in the market. Thus, ginger can be used as an alternative treatment to treat emesis gravidarum before using antiemetic drugs. The content of ginger drink (wedang jahe) is safe from harmful ingredients because it can be made at home. Thus, pregnant women do not have to worry about harming their pregnancy and fetus (Indrayani et al., 2018).

Ginger is an effective alternative non-pharmacological treatment to treat nausea and vomiting of pregnancy (Thomson et al., 2014). The discovery of the effectiveness of ginger in reducing nausea and vomiting in pregnancy is a potential health technology assessment that can be recommended in midwifery practice. However, a comprehensive analysis is needed regarding the use of ginger in reducing complaints of nausea and vomiting in pregnancy. Therefore, this analysis was conducted to determine how the effect and safetyness of ginger in reducing nausea and vomiting in pregnancy.

\section{Methods}

The method employed in this analysis was a narrative review method. The topic in this study that was studied by the researchers through the results of articles in previous journals is the effect of ginger to reduce nausea and vomiting in pregnant women.

\subsection{Research Question}

Table 1. PICO Framework

\begin{tabular}{cccc}
\hline P (Population) & I (Intervention) & C (Comparison) & O (Outcomes) \\
\hline Pregnant women & Giving ginger & Not given ginger & $\begin{array}{l}\text { Ginger decreases nauseous } \\
\text { vomit on pregnant women }\end{array}$ \\
\hline
\end{tabular}

Based on the framework above, the narrative review question chosen is how does ginger affect nausea and vomiting in pregnant women?

\subsection{Search Strategy Design}

The databases used in the source search were Wiley Online Library, PubMed, and Science Direct. The search using the Wiley Online Library database was accessed through the Unisa Library. PubMed was accessed through Google while Science Direct was accessed through PNRI. The search strategy was to enter keywords in the search process that was entered using Medical Subject Headings (MeSH) namely "Pregnant* OR Prenatal* OR Antenatal* AND Ginger* AND Nausea* AND Vomit*". The inclusion criteria in the article search were articles published from 2011 to 2021, articles in English, and discussing the effectiveness of ginger to treat nausea and vomiting in pregnant women. Article exclusion criteria were in the form of opinion articles or commentaries and book reviews. 


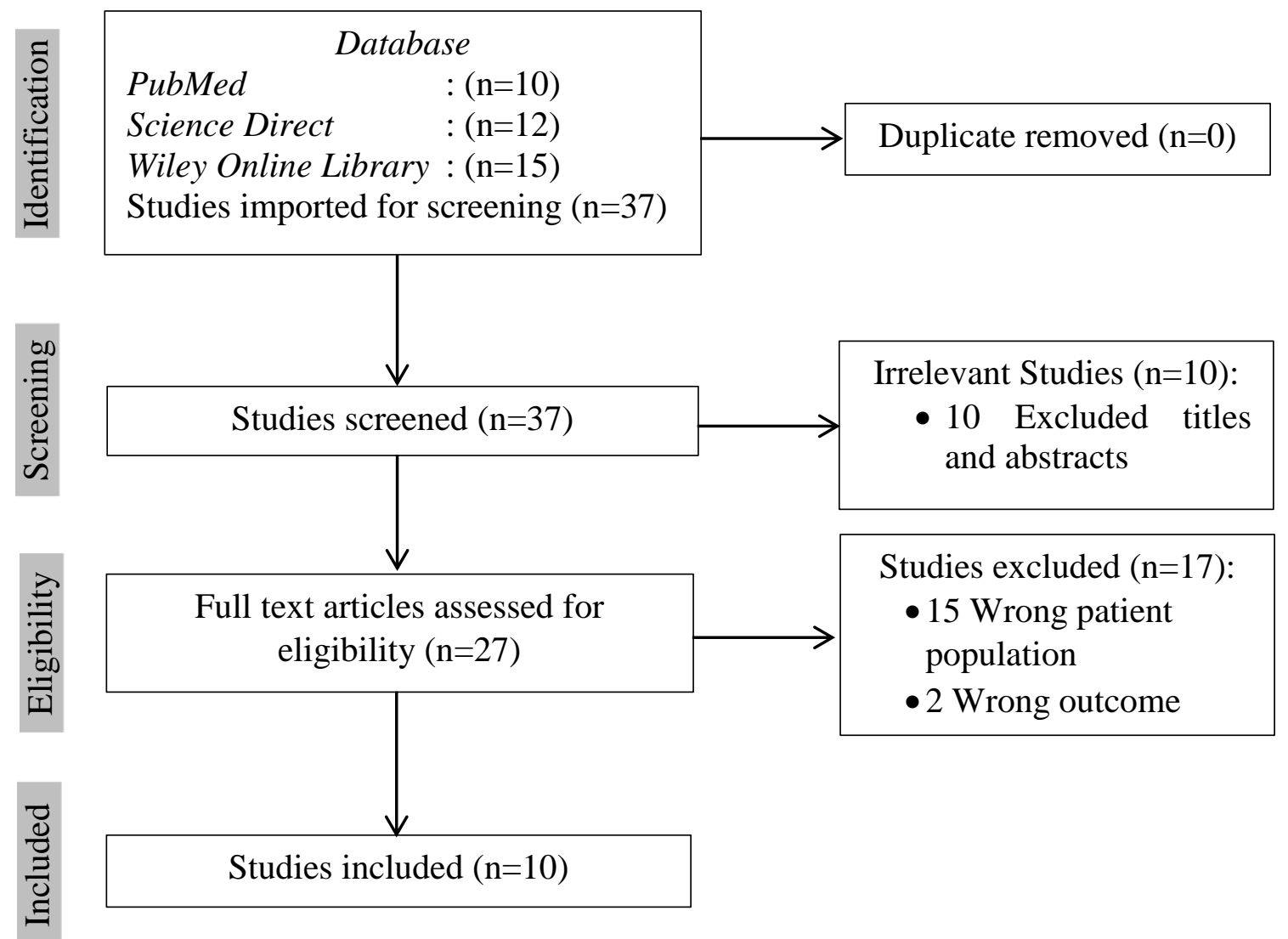

Fig. 1. Flowchart Prism 
After finding 10 relevant articles to answer the question of this narrative review, the next stage was data charting.

Table 2. Data Charting

\begin{tabular}{|c|c|c|c|c|c|c|c|}
\hline No & $\begin{array}{c}\text { Author/ Year/Title/ } \\
\text { Grade }\end{array}$ & Country & Aim & $\begin{array}{c}\text { Type of } \\
\text { Research }\end{array}$ & Data Collection & $\begin{array}{l}\text { Participants/ } \\
\text { Sample Size }\end{array}$ & Result \\
\hline A1 & $\begin{array}{c}\text { (Thomson et al., 2014) } \\
\text { Effects of Ginger for } \\
\text { Nausea and Vomiting in } \\
\text { Early Pregnancy: A Meta- } \\
\text { Analysis }\end{array}$ & Canada & $\begin{array}{c}\text { To critically examine and } \\
\text { synthesize available data from } \\
\text { good-quality randomized } \\
\text { clinical trials to evaluate the } \\
\text { efficacy of ginger in treating } \\
\text { nausea and vomiting of } \\
\text { pregnancy. }\end{array}$ & $\begin{array}{l}\text { A meta-analysis of } \\
\text { clinical trials }\end{array}$ & $\begin{array}{c}\text { Databases used: } \\
\text { PubMed and Embase, } \\
\text { CINAHL, Cochrane } \\
\text { Library, EBM review }\end{array}$ & $\begin{array}{l}135 \text { potentially relevant } \\
\text { records were identified; } \\
\text { only } 6 \text { studies met the } \\
\text { final criteria. }\end{array}$ & $\begin{array}{c}\text { Ginger is an effective non- } \\
\text { pharmacological option for treating } \\
\text { nausea and vomiting of pregnancy due } \\
\text { to the inherent heterogeneity of } \\
\text { available studies. Ginger } \\
\text { administration was better than placebo } \\
\text { in treating nausea and vomiting of } \\
\text { early pregnancy when administered at } \\
\text { a dose of about } 1 \mathrm{~g} / \text { day for a duration } \\
\text { of at least } 4 \text { days. }\end{array}$ \\
\hline $\mathrm{A} 2$ & $\begin{array}{c}\text { (ElHajj et al., 2020) } \\
\text { Herbal medicine use } \\
\text { among pregnant women } \\
\text { attending antenatal clinics } \\
\text { in } \\
\text { Lusaka Province, Zambia: } \\
\text { A cross-sectional, } \\
\text { multicentre study. }\end{array}$ & Zambia & $\begin{array}{l}\text { To determine the prevalence } \\
\text { and pattern of HM use during } \\
\text { pregnancy in Lusuka } \\
\text { Province, Zambia. }\end{array}$ & Quantitative & $\begin{array}{l}\text { Survey based study } \\
\text { (managed by ther } \\
\text { interviewer) }\end{array}$ & $\begin{array}{l}446 \text { pregnant women } \\
\text { who attended the } \\
\text { antenatal clinic in June- } \\
\text { July } 2019\end{array}$ & $\begin{array}{l}\text { The most commonly used herbs were } \\
\text { lemon for nausea/vomiting and the } \\
\text { common cold, soybeans for an energy } \\
\text { boost, ginger for colds and } \\
\text { nausea/vomiting, and aloe vera for } \\
\text { skincare. The perceived safety of HM } \\
(37.6 \%) \text { and its complementary } \\
\text { measures with conventional medicines } \\
\text { (35.3\%) were the main reasons for } \\
\text { using HM. }\end{array}$ \\
\hline A3 & $\begin{array}{l}\text { (Matthews et al., 2015) } \\
\text { Interventions for nausea } \\
\text { and vomiting in early } \\
\text { pregnancy (Review) }\end{array}$ & Irland & $\begin{array}{l}\text { To assess the effectiveness of } \\
\text { safety of all interventions for } \\
\text { nausea, vomiting in early } \\
\text { pregnancy up to } 20 \text { weeks } \\
\text { gestation. }\end{array}$ & $\begin{array}{l}\text { Intervention } \\
\text { Review: a } \\
\text { randomized } \\
\text { controlled trials }\end{array}$ & $\begin{array}{l}\text { Review method based } \\
\text { on standard template } \\
\text { used by Cochrane } \\
\text { Pregnancy and } \\
\text { Childbirth Group. }\end{array}$ & $\begin{array}{c}\text { Pregnant women } \\
\text { experiencing nausea, } \\
\text { vomiting (but not } \\
\text { hyperemesis } \\
\text { gravidarium), for whom } \\
\text { inclusion to the trial } \\
\text { lasted until } 20 \text { weeks } \\
\text { gestation. } \\
\end{array}$ & $\begin{array}{l}\text { The use of ginger products may help } \\
\text { women, but evidence for their } \\
\text { effectiveness is limited and } \\
\text { inconsistent, although three recent } \\
\text { studies support ginger over placebo. } \\
\text { Ginger could be administered in the } \\
\text { form of syrup, capsules, or biscuits. }\end{array}$ \\
\hline A4 & $\begin{array}{l}\text { (Saberi et al., 2014) } \\
\text { Effect of Ginger on } \\
\text { Relieving Nausea and } \\
\text { Vomiting in Pregnancy: A } \\
\text { Randomized, Placebo- } \\
\text { Controlled Trial }\end{array}$ & Iran & $\begin{array}{l}\text { To see how helpful ginger is } \\
\text { at treating nausea and } \\
\text { vomiting in pregnant women. }\end{array}$ & $\begin{array}{c}\text { A Randomized, } \\
\text { Placebo-Controlled } \\
\text { Trial }\end{array}$ & $\begin{array}{l}\text { Data collection using } \\
\text { evaluation form. }\end{array}$ & $\begin{array}{l}120 \text { pregnant women } \\
\text { who experience } \\
\text { symptoms of mild to } \\
\text { moderate nausea and } \\
\text { vomiting with } \\
\text { gestational age below } \\
16 \text { weeks. }\end{array}$ & $\begin{array}{l}\text { The use of ginger is effective in } \\
\text { reducing mild to moderate nausea and } \\
\text { vomiting at gestational age before } 16 \\
\text { weeks by giving } 250 \mathrm{mg} \text { of ginger } \\
\text { capsules as many as } 12 \text { grains, which } \\
\text { are consumed } 3 \text { times a day. }\end{array}$ \\
\hline
\end{tabular}




\begin{tabular}{|c|c|c|c|c|c|c|c|}
\hline A5 & $\begin{array}{c}\text { (Hasan-Ul-Bari \& } \\
\text { Ahmed, 2018) } \\
\text { The use of medicinal } \\
\text { plants by pregnant women } \\
\text { in Africa: a systematic } \\
\text { review }\end{array}$ & Africa & $\begin{array}{l}\text { To analyze the prevalence of } \\
\text { MP use during pregnancy, } \\
\text { regional distribution, type and } \\
\text { prevalence, nature of MP, } \\
\text { potential health risks, and } \\
\text { consensus on MP use, and } \\
\text { suggests relevant measures to } \\
\text { reduce negative effects on } \\
\text { pregnancy. }\end{array}$ & Systematic Review & $\begin{array}{c}\text { Database Used } \\
\text { (Medline, Embase, } \\
\text { African } \\
\text { Journals OnLine, } \\
\text { Google Scholar and } \\
\text { Biological Abstracts }\end{array}$ & $\begin{array}{l}\text { A total of } 3,659 \text { articles } \\
\text { were found, but only } \\
303 \text { articles were fit and } \\
50 \text { were used for a } \\
\text { systematic review }\end{array}$ & $\begin{array}{l}\text { The prevalence of MP use by pregnant } \\
\text { women varies from } 2 \% \text { to } 100 \% \text {. } \\
\text { Twenty-eight studies (56\%) defined } \\
\text { one or more plant species used as MP } \\
\text { during pregnancy. The main reasons } \\
\text { for using MP are relieving nausea and } \\
\text { vomiting during pregnancy (NVP), } \\
\text { stimulation of labor, and facilitation of } \\
\text { labor. The most frequently cited MP } \\
\text { species are Zingiber officinale Roscoe, } \\
\text { Allium sativum L., and Cucurbita pepo } \\
\text { L. These are used to relieve NVP, } \\
\text { motion sickness, and as a nutritional } \\
\text { supplement. The route of } \\
\text { administration is the most common } \\
\text { oral, and few side effects have been } \\
\text { reported }\end{array}$ \\
\hline A6 & $\begin{array}{l}\text { (Ding et al., 2018) } \\
\text { The effectiveness and } \\
\text { safety of ginger for } \\
\text { pregnancy-induced } \\
\text { nausea and vomiting: A } \\
\text { systematic review }\end{array}$ & Australia & $\begin{array}{l}\text { To test the evidence for the } \\
\text { safety and efficacy of ginger } \\
\text { for nausea and vomiting in } \\
\text { pregnancy }\end{array}$ & Systematic Review & $\begin{array}{l}\text { Data were obtained } \\
\text { through literature } \\
\text { search on CINAHL, } \\
\text { Cochrane } \\
\text { library, } \\
\text { MEDLINE } \\
\text { and } \\
\text { TRIP databases }\end{array}$ & $\begin{array}{l}70 \text { articles into } 4 \\
\text { articles used as a } \\
\text { literature review }\end{array}$ & $\begin{array}{c}\text { The research results were identified. } \\
\text { All researches studied found ginger to } \\
\text { be more effective compared to placebo } \\
\text { and vitamin B6 in improving PNV. } \\
\text { Studies suggest that using ginger is } \\
\text { safe. }\end{array}$ \\
\hline A7 & $\begin{array}{l}\text { (Omidvar et al., 2014) } \\
\text { Comparison of ginger } \\
\text { with vitamin B6 in } \\
\text { relieving nausea and } \\
\text { vomiting during } \\
\text { pregnancy }\end{array}$ & Iran & $\begin{array}{l}\text { To determine the effect of } \\
\text { ginger on nausea and } \\
\text { vomiting during pregnancy } \\
\text { compared with vitamin B6 } \\
\text { and placebo. }\end{array}$ & $\begin{array}{l}\text { Quantitative simple } \\
\text { random sampling }\end{array}$ & $\begin{array}{l}\text { Collection using } \\
\text { questionnaire form }\end{array}$ & $\begin{array}{c}120 \text { pregnant women } \\
\text { who experienced nausea } \\
\text { and vomiting under } 16 \\
\text { weeks gestation }\end{array}$ & $\begin{array}{c}\text { There was a significant difference } \\
\text { between the groups in severity of } \\
\text { nausea and frequency of vomiting } \\
(\mathrm{P}<0.001) \text {. The effectiveness of ginger } \\
\text { and B6 is the same in reducing nausea } \\
\text { and vomiting. }\end{array}$ \\
\hline
\end{tabular}




\begin{tabular}{|c|c|c|c|c|c|c|c|}
\hline A8 & $\begin{array}{l}\text { (Javadi et al., 2015) } \\
\text { Comparing the } \\
\text { Effectiveness of Vitamin } \\
\text { B6 and Ginger in } \\
\text { Treatment of Pregnancy- } \\
\text { Induced Nausea and } \\
\text { Vomiting }\end{array}$ & Iran & $\begin{array}{l}\text { To compare the effectiveness } \\
\text { of vitamin B6 ( } 40 \mathrm{mg} \text { twice } \\
\text { daily) and ginger ( } 250 \mathrm{mg} \text { four } \\
\text { times daily) in the treatment } \\
\text { of nausea of pregnancy. }\end{array}$ & $\begin{array}{l}\text { Quantitative } \\
\text { Randomized } \\
\text { controlled trial }\end{array}$ & $\begin{array}{l}\text { Data collection using } \\
\text { questionnaire form }\end{array}$ & $\begin{array}{l}120 \text { pregnant women } \\
\text { under } 17 \text { weeks of } \\
\text { gestation who suffer } \\
\text { from the nausea of } \\
\text { pregnancy }\end{array}$ & $\begin{array}{l}\text { In both groups, treatment with vitamin } \\
\text { B6 or ginger left a significant decrease } \\
\text { in MPUQE scores. The symptom } \\
\text { scores on the day before treatment in } \\
\text { the vitamin B6 and ginger groups were } \\
9.35 \pm 1.97 \text { and } 9.80 \pm 2.03 \text {, } \\
\text { respectively, and were reduced to } 5.98 \\
\pm 1.45 \text { and } 6.28 \pm 1.63 \text {, respectively, } \\
\text { on the fourth day of treatment; } \\
\text { However, the mean changes in the two } \\
\text { groups were not significantly different. } \\
\text { The mean changes in MPUQE scores } \\
\text { in the ginger and vitamin B6 groups } \\
\text { were } 8.32 \pm 2.19 \text { and } 7.77 \pm 1.80, \\
\text { respectively, showing no significant } \\
\text { difference }(=0.172) \text {. }\end{array}$ \\
\hline A9 & $\begin{array}{c}\text { (Izzo et al., 2016) } \\
\text { A Critical Approach to } \\
\text { Evaluating Clinical } \\
\text { Efficacy, Adverse Events } \\
\text { and Drug Interactions of } \\
\text { Herbal Remedies } \\
\text { Angelo }\end{array}$ & Italy & $\begin{array}{l}\text { To provide an overview of the } \\
\text { efficacy and safety, including } \\
\text { drug interactions, based on } \\
\text { systematic reviews or meta- } \\
\text { analyses related to herbal } \\
\text { medicines mainly used in } \\
\text { Western countries. }\end{array}$ & Systematic review & $\begin{array}{l}\text { Data were obtained } \\
\text { from literature search }\end{array}$ & $\begin{array}{l}\text { Systematic review and } \\
\text { meta-analysis articles } \\
\text { published from 2013- } \\
2015\end{array}$ & $\begin{array}{l}\text { Certain herbal medicines have been } \\
\text { shown to be efficacious (e.g., ginger to } \\
\text { prevent and treat nausea and vomiting) }\end{array}$ \\
\hline A10 & $\begin{array}{l}\text { (Bodagh et al., 2019) } \\
\text { Ginger in gastrointestinal } \\
\text { disorders: A systematic } \\
\text { review of clinical trials }\end{array}$ & Iran & $\begin{array}{l}\text { To summarize the current } \\
\text { evidence on the effect of } \\
\text { ginger consumption on } \\
\text { indigestion based on clinical } \\
\text { trials. }\end{array}$ & Systematic review & $\begin{array}{l}\text { Data were obtained } \\
\text { from literature search }\end{array}$ & $\begin{array}{c}\text { Recent studies } \\
\text { evaluating the effects of } \\
\text { ginger consumption in } \\
\text { digestive disorders }\end{array}$ & $\begin{array}{l}\text { Ginger can be considered as a } \\
\text { harmless and possibly effective } \\
\text { alternative option for women suffering } \\
\text { from symptoms of nausea and } \\
\text { vomiting in pregnancy. A daily dose of } \\
1,500 \mathrm{mg} \text { of ginger is useful for } \\
\text { relieving nausea. Ginger poses no risk } \\
\text { for side effects or adverse events } \\
\text { during pregnancy }\end{array}$ \\
\hline
\end{tabular}


Furthermore, the article quality assessment was carried out by conducting a critical appraisal of 10 articles. The instruments used to assess the quality of articles were the Mixed Method Appraisal Tool (MMAT) and Critical Appraisal Skill Program (CASP) Checklist. Categorization of article quality with a grade scale of A (Good), B (Quite Good), and C (Less Good) to assess the quality of each article.

Table 3. MMAT Quantitative Randomized Controlled Trials

\begin{tabular}{cccccccc}
\hline No & Criteria of Methodology Quality & A1 & A2 & A3 & A4 & A7 & A8 \\
\hline 1. & Are there clear research questions? & 2 & 2 & 2 & 2 & 2 & 2 \\
\hline 2. & $\begin{array}{c}\text { Do the collected data allow to address } \\
\text { the research questions? }\end{array}$ & 2 & 2 & 2 & 2 & 2 & 2 \\
\hline 3. & $\begin{array}{c}\text { Is randomization appropriately } \\
\text { performed? }\end{array}$ & 2 & 2 & 2 & 2 & 2 & 2 \\
\hline 4. & $\quad \begin{array}{l}\text { Are the groups comparable at } \\
\text { baseline? }\end{array}$ & 2 & 2 & 2 & 2 & 2 & 2 \\
\hline 5. & Are there complete outcome data? & 2 & 2 & 2 & 2 & 2 & 2 \\
\hline 6. & $\begin{array}{c}\text { Are outcome assessors blinded to the } \\
\text { intervention provided? }\end{array}$ & 1 & 2 & 2 & 1 & 2 & 1 \\
\hline 7. & $\begin{array}{c}\text { Did the participants adhere to the } \\
\text { assigned intervention? }\end{array}$ & 2 & 1 & 1 & 2 & 1 & 2 \\
\hline & Total Value/ Grade & $13 / \mathrm{A}$ & $13 / \mathrm{A}$ & $13 / \mathrm{A}$ & $13 / \mathrm{A}$ & $13 / \mathrm{A}$ & $13 / \mathrm{A}$ \\
\hline
\end{tabular}

Table 4. Critical Appraisal Skill Program (CASP): Systematic Review

\begin{tabular}{cccccc}
\hline No & Criteria of Methodology Quality & A5 & A6 & A9 & A10 \\
\hline 1. & Did the review address a clearly focused question? & 2 & 2 & 2 & 2 \\
\hline 2. & Did the authors look for the right type of papers? & 2 & 2 & 2 & 2 \\
\hline 3. & $\begin{array}{c}\text { Do you think all the important, relevant studies were } \\
\text { included? }\end{array}$ & 2 & 2 & 2 & 1 \\
\hline 4. & Did the review's authors do enough to assess quality of the \\
included studies? & 2 & 2 & 2 & 1 \\
\hline 5. & If the results of the review have been combined, was it \\
reasonable to do so? & 2 & 2 & 2 & 2 \\
\hline 6. & What are the overall results of the review? & 1 & 2 & 2 & \\
\hline 7. & How precise are the results? & 2 & 2 & 2 & 2 \\
\hline 8. & Can the results be applied to the local population? & 2 & 1 & 2 & 1 \\
\hline 9. & Were all important outcomes considered? & 2 & 2 & 2 & 2 \\
\hline 10. & Are the benefits worth the harms and costs? & 1 & 1 & 1 & 1 \\
\hline & Total Values/ Grade & $18 / \mathrm{A}$ & $18 / \mathrm{A}$ & $18 / \mathrm{A}$ & $15 / \mathrm{B}$ \\
\hline
\end{tabular}




\section{Results/Findings}

\subsection{Article Characteristics}

Based on the results of critical appraisal with MMAT and CASP from 10 selected articles, 6 articles (A1, A2, A3, A4, A7, A8) used a quantitative randomized controlled trial and 4 articles (A5, A6, A9, A10) used systematic reviews.

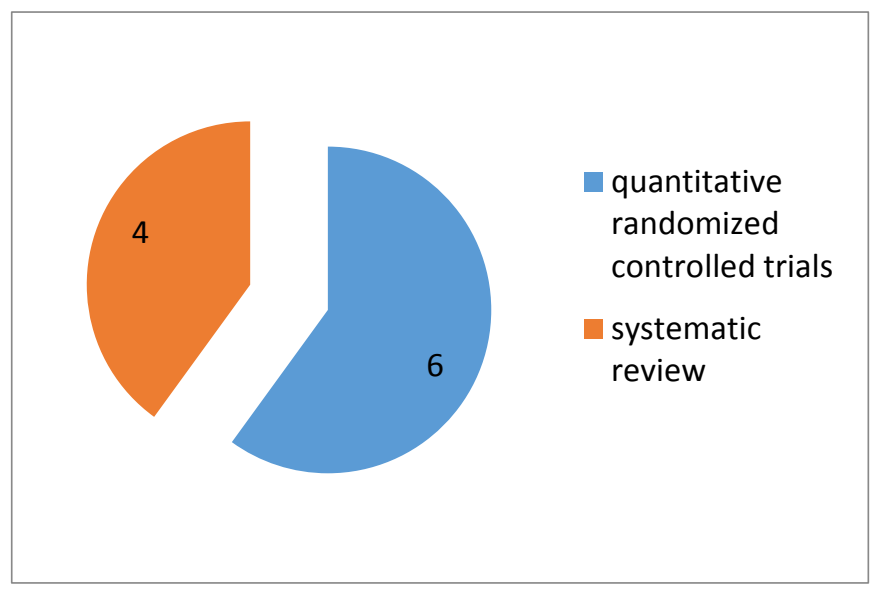

Fig. 2. Article based on study design

Based on the quality of the articles that have been critically appraised, 9 articles obtained grade $\mathrm{A}$ (A1, A2, A3, A4, A5, A6, A7, A8 A9) and 1 article (A10) obtained grade B.

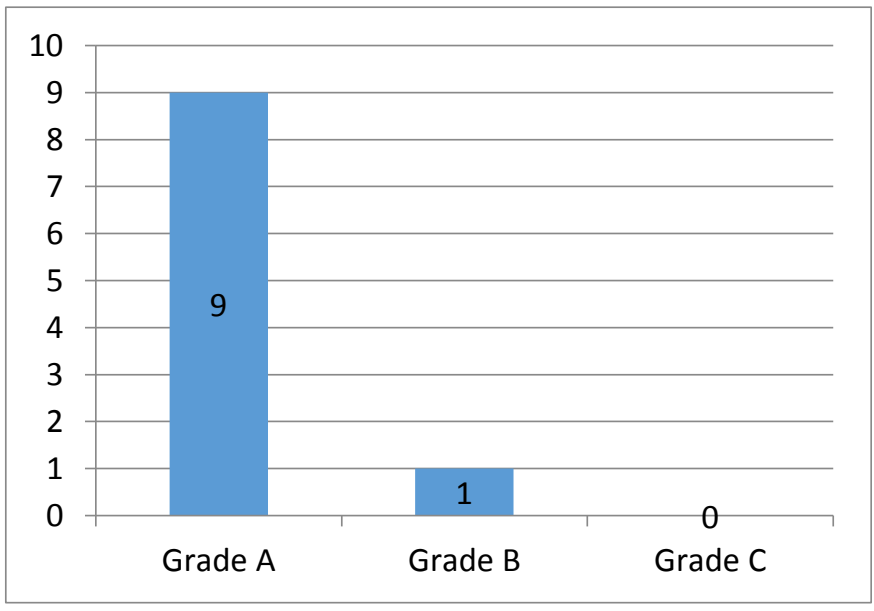

Fig. 3. Articles by article quality

Based on critical appraisal, there are 6 research articles conducted in developing countries including, Afrika (1), Iran (4), Zambia (1), and 4 articles conducted in developed countries, including Australia (1), Italia (1), Ireland (1). Canada (1). 


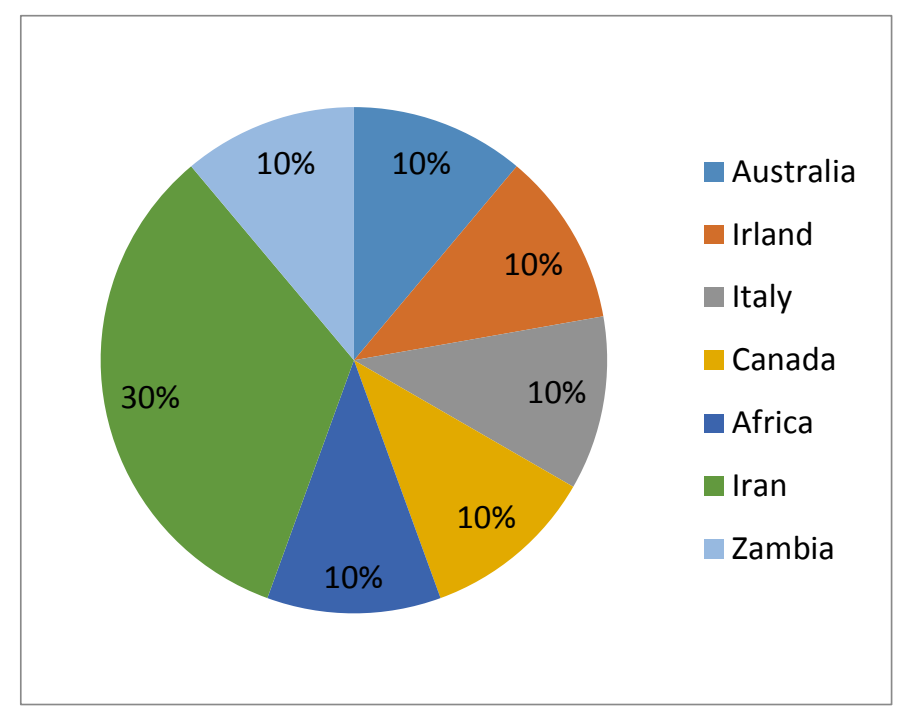

Fig. 4. Articles by country

\section{Discussion}

\section{1) The Effectiveness of Ginger in Reducing Nausea and Vomiting Pregnancy}

\section{a) Effectiveness}

Based on selected articles that found the theme of ginger's effectiveness in reducing nausea and vomiting, more than half of women attending antenatal clinics in Lusaka Province, Zambia, reported using herbal medicines during pregnancy. A wide variety of herbal remedies were cited by study participants, with the most frequently reported ones being lemon, soy, ginger, and aloe vera. Overall, $57.8 \%$ of participants reported using HM during their current pregnancy, with a mean of 2.0-1.5 drugs/woman. Logistic regression analysis showed that the use of HM was significantly associated with HM in previous pregnancies $(\mathrm{p}<0.001)$ and willingness to use HM in the future $(\mathrm{p}<0.001)$. The most commonly used herbs are lemon for nausea/vomiting and the common cold, soybeans for an energy boost, ginger for colds and nausea/vomiting, and aloe vera for skincare. The perceived safety of HM (37.6\%) and its complementary measures with conventional medicines (35.3\%) are the main reasons for using HM (ElHajj et al., 2020).

A total of 3,659 studies using MP were found, but only 303 articles received a full-text assessment for eligibility. Accordingly, only 50 scientific papers were eligible for systematic review. The prevalence of MP use by pregnant women varies from $2 \%$ to $100 \%$. Twenty-eight studies (56\%) identified one or more plant species used as MP during pregnancy. The main reasons for using MP are to relieve nausea and vomiting during pregnancy (NVP), stimulate labor, and facilitate labor. The most frequently cited MP species are Zingiber officinale Roscoe, Allium sativum L., and Cucurbita pepo L. These are used to relieve NVP, motion sickness and as a nutritional supplement. The most common route of administration is oral and few side effects have been reported (Hasan-Ul-Bari \& Ahmed, 2018). They are significantly more effective than placebo in reducing frequency. The common side effects are mild and rare. Ginger which is orally administered is able to reduce vomit and nausea intensity. It can be concluded that the best available evidence suggests that ginger is a safe and effective treatment for PNV. However, there is still uncertainty regarding maximal treatment, the consequences of overdose, and potentially important areas for future research (Ding et al., 2018).

Certain herbal remedies have been shown to be efficacious (e.g., ginger to prevent and treat nausea and vomiting), whereas others have been shown to be effective for certain indications but 
not for other indications (e.g., ginseng to improve glucose metabolism, but not Alzheimer's) (Izzo et al., 2016).

Herbal medicine as a therapeutic approach such as garlic, chamomile, peppermint, sea oak, and ginger is used to treat nausea and vomiting of pregnancy. As a spice, ginger (Zingiber officinale) has a long history in food and pharmaceutical applications and is widely used in traditional medicine, especially in China, Japan, India, and Iran to treat various ailments, especially nausea and vomiting in pregnancy. Ginger has been used as a treatment for nausea and vomiting in pregnancy. Side effects of ginger did not result in abortion or increased birth deficit and maternal complications observed after administration of ginger. Among the forms of ginger available, ginger tea, biscuits, and capsules can be mentioned. Consumption of the latter is easier on the stomach and contains dried ginger which is more effective than fresh root ginger.

In early pregnancy, the use of chemical drugs should be avoided as much as possible because of the potential for teratogenic effects which can lead to an increasing trend for alternative therapies. Ginger has been used as an anti-nausea agent in traditional Indian, Chinese, and Iranian medicine. In a different study, the use of ginger did not show any adverse effects on pregnancy outcomes. Ginger was more effective than placebo in reducing pregnancy nausea. In several studies, the effectiveness of ginger has been reported to be equivalent to or more than vitamin B6 (Javadi et al., 2015).

Based on the evidence from this systematic review, ginger can be considered a harmless and possibly effective alternative option for women who suffer from symptoms of nausea and vomiting during pregnancy. It seems that splitting the daily dose lower than $1,500 \mathrm{mg}$ of ginger is beneficial for relieving nausea. Ginger does not pose a risk or side effects during pregnancy. Ginger and its polyphenols have been shown to target several signaling molecules which provide the basis for their use against multifactorial human diseases such as cancer (Bodagh et al., 2019).

\section{b) Ineffective}

The use of ginger has long been known to have various health benefits. The function of ginger is commonly used to describe nausea and vomiting of pregnancy. The use of ginger in conditions of hyperemesis gravidarum or excessive nausea and vomiting in pregnancy is not effective when using herbal ginger treatment. Hyperemesis gravidarum should be treated with pharmacological drugs to avoid dehydration and danger signs in pregnant women (Ashaba et al., 2017).

\section{2) The Safety of Using Ginger in Reducing Nausea/Vomiting in Pregnancy}

The preparation of the theme mapping in the narrative review compiled by the researchers for the second theme, the safety of using ginger, in which the sub-themes determined was safe and unsafe. Based on the results of the theme mapping, the researchers found articles stating that it is safe to use ginger as a therapy for nausea and vomiting. Based on the results of Viljeon (2020) research, ginger is considered less effective in reducing the symptoms of nausea vomiting in pregnancy and is only used as a harmless or safe alternative (Viljoen et al., 2014). Commonly used are lemon for nausea/vomiting and the common cold, soybean for an energy boost, ginger for colds and nausea/vomiting, and aloe vera for skincare. The perceived safety of Herbal Medicine (37.6\%) and its complementary action with conventional medicines $(35.3 \%)$ were the main reasons for using Herbal Medicine (Javadi et al., 2015). The safety and effectiveness of oral ginger preparations in pregnant women with nausea and vomiting explained through a review of studies that ginger was more effective than placebo and vitamin B6 in treating nausea and vomiting in pregnancy and also showed that the use of ginger in women with nausea and vomiting was safe to use (Ahmed et al., 2020; Barney et al., 2016). The results found and the selection process did not find ginger to be unsafe in overcoming nausea and vomiting in pregnant women. The pharmacological function of ginger is one of them is antimetic (anti-vomiting). One of the chemicals in ginger is used as ingredient laxative antigas, and antacid medication that are able to reduce nausea and vomiting in pregnant women (Timba et al., 2019). The use of ginger during pregnancy does not increase the risk for any of the following pregnancy outcomes like perinatal death, low birth weight, preterm birth, and low Apgar score (Stanisiere et al., 2018). 
3) Other Therapies to Reduce Nausea and Vomiting during Pregnancy

The next theme that was found based on the selected articles was related to other therapies that can be used to reduce nausea and vomiting in pregnancy.

\section{a) Pharmacology}

One of the most common and unpleasant in pregnancy is pregnancy-induced nausea and complications from vomiting (PNV). These symptoms are often experienced by women in the first trimester of pregnancy; affect between fifty and eighty percent of pregnant women. A number of complementary and primary drugs have been recommended or prescribed for women with PNV. The use of several pharmacological agents to relieve the symptoms of PNV during the period of embryonic organogenesis is contraindicated in two important cases confirming the risks associated with conventional pharmaceutical drugs: Thalidomide, for example, is associated with the development of severe limb defects in utero, Bendectin - a combination of pyridoxine and antihistamines - is believed to cause congenital malformations, and while a causal relationship has never been documented. The drug has been the subject of several lawsuits and has subsequently been withdrawn from the Vitamin B6 market (a recently recommended treatment pyridoxine for symptomatic relief of PNV (Maternity et al., 2017). Cochrane's systematic search of the literature was conducted using the MEDLINE Database and TRIP Data search and identified nineteen potentially relevant studies. Of these, fifteen were rejected because they were not RCTs. Three studies were assessed for adverse events. Ozgoli et al found this resulted in four prospective, parallel design, randomized controlled trials, all of which except one were double-blind with both ginger and placebo treatments. the main side effects reported were burned sensation (ginger $2 \%$ vs vitamin B6 2\%) and burp (ginger 9\% vs. vitamin B6 0\%) (Dyna \& Febriani, 2020).

This study was conducted to compare the effects of vitamin B6, ginger, and placebo in the treatment of gestational nausea and vomiting in pregnant women. This randomized double-blind clinical trial was conducted on 120 pregnant women referred to a health center in Amol/Iran. The selection was done by a simple random sampling method. Ginger capsules (Zintoma, $250 \mathrm{mg}$ ), Vitamin B6 (40 mg) orally, and placebo (sugar $40 \mathrm{mg}$ ) were coded and packaged in a similar enclosure at the Pharmacology Laboratory. Zintoma contains dry powder of zingiber rhizome. The active ingredients of zintoma are Alkaloid (e.g., Gentialutine, gentianine), glycosides (anaroswerin, amaropanin), essential oils (bisabolene, zingiberene, gingerol, zingiberole) (Kustriyanti \& Putri, 2019). A week after treatment initiation, participants' treatment status was evaluated using a Likert scale. It was evident from the results that symptom severity was dramatically reduced in 60.6, 42.7, and $61 \%$ ginger, placebo, and group B6, respectively. However, symptoms severity in some subjects worsened $(32.2,8.8$, and $18.3 \%$ in the placebo, B6, and ginger groups). $46 \%$ of placebo recipients versus $16 \%$ B6 and $27.6 \%$ ginger recipients experienced problems such as severe nausea and vomiting, abdominal pain, and heartburn during treatment. The severity of nausea and vomiting in the placebo group in some cases led to discontinuation of the drug and the use of other treatment methods. Abdominal pain, heartburn, and increased nausea were also reported in $10.2 \%$ of ginger recipients (Cholifah \& Nuriyanah, 2019).

\section{b) Non-pharmacologic}

Nausea and vomiting in early pregnancy can be handled by consuming ginger. Ginger is a nonpharmacological therapy. Ginger can be consumed in the form of syrup, capsules, or biscuits to relieve nausea (Rofi'ah et al., 2020). Furthermore, ginger in the form of aromatherapy can inhibit serotonin receptors and induce antiemetic effects on the gastrointestinal and central nervous systems which can use as a therapy to reduce nausea and vomiting (Hoffman et al., 2020). Ginger can be used as an alternative option that is harmless and may be effective for women who suffer from symptoms of nausea and vomiting in pregnancy. In order to ensure the quality of care, midwives must bring a variety of competencies including clinical knowledge and skills with interpersonal and cultural competencies (Rosyidah et al., 2019).

In addition to ginger, other herbal remedies can be done by giving lemon. Lemon is one of the most commonly used herbs for nausea/vomiting (Stanisiere et al., 2018). Lemon has an effect in reducing nausea and vomiting in first-trimester pregnant women (Saberi et al., 2014). When essential oils are inhaled, volatile molecules will carry the aromatic elements present in the oil content to the top of the nose which makes the nasal hairs vibrate which functions as receptors that will deliver electrochemical messages to the central nervous system which activates the emotional 
and memory centers of a person, which in turn will deliver messages back throughout the body through the circulatory system, causing feelings of pleasure, relaxation, calm, or arousal (Negarandeh et al., 2020).

\section{Conclusion}

Ginger is one of the herbal remedies that are effective in reducing nausea and vomiting in pregnancy and is safe for consumption by pregnant women. However, according to an article, the use of ginger is not effective in pregnant women who experience hyperemesis gravidarum.

\section{Acknowledgment}

The researchers would like to thank the Master of Midwifery Program, Faculty of Health Sciences, Aisyiyah University, Yogyakarta, which provided the facilities to conduct this study.

\section{References}

Afriyanti. (2017). The Effectiveness of Hot Ginger Drink To Decrease Nauseous Vomit on Pregnant Women at PMB YF Bukittingi City Year of 2017. Human Care Journal, 2(3). https://doi.org/10.32883/hcj.v2i3.642

Ahmed, Aktar, Farnaz, Ray, Awal, Hassan, Shafique, Hasan, Quayyum, Jafarovna, Kobeissi, Tahir, E., \& Chawla. (2020). Challenges and strategies in conducting sexual and reproductive health research among Rohingya refugees in Cox's Bazar, Bangladesh. Confl Health, 14(1), 83. https://doi.org/10.1186/s13031-020-00329-2

Ashaba, Kaida, Burns, O’Neil, Dunkley, Psaros, \& Matthews. (2017). Understanding coping strategies during pregnancy and the postpartum period: A qualitative study of women living with HIV in rural Uganda. BMC Pregnancy and Childbirth. 17(1), 1-10. https://doi.org/10.1186/s12884-017-1321-9

Barney, Emerita, \& Perkinson. (2016). OCCUPATIONAL THERAPY with Aging Adults: Promoting Quality of Life through Collaborative Practice (J. of C.-C. Gerontology (ed.). In Elsevier Inc.

Bodagh, N., Maleki, \& Hekmatdoost. (2019). Ginger in gastrointestinal disorders: A systematic review of clinical trials. Food Science and Nutrition, 7(1), 96-108.

Cholifah, \& Nuriyanah. (2019). Lemon Aromatherapy Decreasing Nauseous Vomit on Pregnant Women in Trimester I. Journal of Midwifery Midwiferia, 4(1), 36. https://doi.org/10.21070/mid.v4i1.1844

Ding, Leach, \& Bradley. (2018). The effectiveness and safety of ginger for pregnancy-induced nausea and vomiting: A systematic review. Women and Birth, 26(1), e26-e30. https://doi.org/10.1016/j.wombi.2012.08.001

Dyna, \& Febriani. (2020). Giving Ginger Oil Aromatherapy Towards Nauseous Vomit Frequency on Pregnant Women Morning Sickness. Nursing Journal of Health Science Kendal, 12(1), 4146.

ElHajj, Sitali, Vwalika, \& Holst. (2020). Herbal medicine use among pregnant women attending antenatal clinics in Lusaka Province, Zambia: A cross-sectional, multicentre study. Complementary Therapies in Clinical Practice, 40(1), 101218. https://doi.org/10.1016/j.ctcp.2020.101218

Hasan-Ul-Bari, \& Ahmed. (2018). Ensuring sexual and reproductive health and rights of Rohingya women and girls [Letter]. Lancet, 392(10163), 2439-2440. https://doi.org/10.1016/S01406736(18)32764-8

Hoffman, Bennet, \& Mar, D. (2020). EVIDENCE BASED PRACTICE : ACROSS THE HEALTH PROFESSIONS (S. Silva (Ed.). In Elsevier Australia. 
Indrayani, Burhan, \& Widiyanti. (2018). The Effectiveness of Giving Hot Ginger Drink Towards Nausea and Vomit on Pregnant Women of Trimester I in North Bengkulu Regency Year of 2017. Journal of Health Science and Technology, 5(2), 201-211. https://doi.org/10.32668/jitek.v5i2.29

Izzo, Hoon-Kim, Radhakrishnan, \& Williamson. (2016). A Critical Approach to Evaluating Clinical Efficacy, Adverse Events and Drug Interactions of Herbal Remedies. Phytotherapy Research, 30(5), 691-700. https://doi.org/10.1002/ptr.5591

Javadi, H. S., Salehi, \& Mashrabi. (2015). Comparing the Effectiveness of Vitamin B6 and Ginger in Treatment of Pregnancy-Induced Nausea and Vomiting. Obstetrics and Gynecology International, 1-4. https://doi.org/10.1155/2013/927834

Kustriyanti, \& Putri. (2019). Ginger and Lemon Aromatherapy To Relieve Nausea and Vomiting in $\begin{array}{lllll}\text { Pregnancy. Jurnal } & \text { Keperawatan }\end{array}$ https://doi.org/10.20884/1.jks.2019.14.1.868

Mardiyanti, \& Zuwariyah. (2019). The Effectiveness of Jsj (Jin Shin Jyutsu) in Addressing Emesis of Gravidarum in Pregnant Women At Pmb Ika Mardiyanti Sidoarjo. Nurse and Health: Jurnal Keperawatan, 8(1), 36-42. https://doi.org/10.36720/nhjk.v8i1.57

Maternity, Ariska, \& Sari. (2017). Nausea and Vomit on Pregnant Women Trimester One. Journal of Midwifery, 2(3), 115-120.

Matthews, Haas, O’Mathúna, \& Dowswell. (2015). Interventions for nausea and vomiting in early pregnancy. Cochrane Database of Systematic Reviews, 9(1).

Murdiana. (2019). The Therapy of Nausea and Vomit on Pregnancy in Outpatient of Hospital D Class.

Negarandeh, Eghbali, Janani, Dastaran, \& Saatchi. (2020). Auriculotherapy as a means of managing nausea and vomiting in pregnancy: A double-blind randomized controlled clinical trial. Complementary Therapies in Clinical Practice, 40(1), 101177.

Omidvar, Firouzbakht, Nikpour, \& Jamali. (2014). Comparison of ginger with vitamin B6 in relieving nausea and vomiting during pregnancy. AYU (An International Quarterly Journal of Research in Ayurveda), 35(3), 289. https://doi.org/10.4103/0974-8520.153746

Rofi'ah, Handayani, \& Rahmawati. (2020). The Effectiveness of Ginger and Lemon Grass Consumption in Overcoming Nausea and Vomit. 7.

Rosyidah, Koning, \& Ormel. (2019). Quality of maternal health care in Indonesia. Journal of Health Technology Assessment in Midwifery, 2(1), 10-22. https://doi.org/10.31101/jhtam.924

Saberi, Sadat, Kalahroudi, \& Taebi. (2014). Effect of Ginger on Relieving Nausea and Vomiting in Pregnancy: A. Nurs Midwifery Stud. A. Nurs Midwifery Stud, 3(1), 1-6.

Stanisiere, Mousset, \& Lafay. (2018). How Safe Is Ginger Rhizome for Decreasing Nausea and Vomiting in Women during Early Pregnancy? Foods. 7(4), 50. https://doi.org/10.3390/foods7040050

Thomson, Corbin, \& Leung. (2014). Effects of ginger for nausea and vomiting in early pregnancy: A meta-analysis. Journal of the American Board of Family Medicine, 27(1), 115-122. https://doi.org/10.3122/jabfm.2014.01.130167

Timba, Giri, \& Panchal. (2019). Health benefits and possible Risks of Turmeric , Garlic and Ginger : A short Review. International Research. Journal of Engineering and Technology, 6(4), 46544659 .

Viljoen, Visser, Koen, \& Musekiwa. (2014). A systematic review and meta-analysis of the effect and safety of ginger in the treatment of pregnancy-associated nausea and vomiting. Nutrition Journal, 13(1), 20. https://doi.org/10.1186/1475-2891-13-20 